\title{
Spontaneous humour and Malaysia's democratic breakthrough in 2018
}

\author{
Shanon Shah \\ King's College London, UK \\ shanonshah@gmail.com
}

\begin{abstract}
The 2018 Malaysian general election was the first democratic change of government in the nation's modern history. The victory of the Pakatan Harapan (Alliance of Hope-PH) coalition surprised several observers within and outside the country, especially considering the intensified repression employed by the outgoing Barisan Nasional (National Front - BN) ruling coalition leading up to the polls, including media censorship, the silencing of political opponents, and the manipulation of Islamism and ethnic Malay nationalism. This article examines the role of spontaneous, conversational humour in constructing a viable political identity for the PH. It does this by considering humorous moments during press conferences and similar media events held by the PH coalition, led by its designated choice for prime minister, Mahathir Mohamad. This article aims to contribute to the scholarship on the role of humour in identity construction and political campaigning.
\end{abstract}

Keywords: humour, politics, identity, Malaysia, elections

\section{Introduction}

The lead-up to Malaysia's fourteenth general election in May 2018 was defined by the everescalating political repression by the incumbent Barisan Nasional (BN - National Front) government. These tactics included interfering with independent state institutions and manipulating them in unprecedented ways, even considering the country's history of authoritarian government. At the start of the election campaign, for instance, the Election Commission banned the opposition coalition, Pakatan Harapan (PH - Alliance of Hope), from including images of its leader and designated prime minister, Mahathir Mohamad, and his de facto running mate, Anwar Ibrahim, in its campaign materials. This was meant to stymie the potential combined support for the two leaders, given their unanticipated rapprochement after nearly two decades of enmity (summarised in Section 4). Given the overall climate of increasing censorship and intimidation of political opponents, the Commission's directive only seemed to reinforce conventional predictions that the $\mathrm{BN}$ would comfortably retain government.

Instead, the PH scored a major upset, resulting in the first change of government after 55 years of Malaysia's existence (or 61 years, considering the independence of Malaya, now West 
Malaysia, from British rule in 1957). This article proposes that, in helping to construct a political identity for the PH coalition despite its untested and unlikely alliances, spontaneous humour was one of several factors that contributed to this result. It discusses the role of humour in the context of what some academic and media observers have labelled the "Mahathir effect" in leading the PH to victory (Abdullah 2019: 528). According to this perspective, Mahathir ${ }^{1}$ provided the opposition bloc with a much-needed "credibility boost" in its uphill battle against the BN regime (Abdullah 2019: 522). At the same time, according to numerous analysts and critics, Mahathir also bears responsibility for undermining the country's independent and democratic institutions during his 22 years in power (1981-2003) (Hutchinson 2018: 583). Furthermore, focusing on the "Mahathir effect" ignores the "broader societal shifts" that contributed to the "political rupture" of the 2018 elections, such as the role of emotions in contemporary political campaigning, the implosion of the $\mathrm{BN}$ regime due to the colossal 1MDB corruption scandal, and the BN's failure to connect with younger voters (Welsh 2018: 87).

Whilst these caveats are necessary, it is clear that Mahathir did play a significant role in helping the PH to secure electoral victory. This article therefore examines the role of humour alongside these institutional, demographic, and economic factors during the historic 2018 elections. Consider Mahathir's off-the-cuff response in his first press conference when he declared victory for the PH through which, at age 92, he became the world's oldest elected leader. In fact, the election campaign was defined by repeated questions and concerns about his health and advanced age. Yet, addressing journalists and supporters at 3am, Mahathir (in the words of the BBC) "quipped wryly to the expectant crowd" - "Yes, yes, I am still alive" (BBC 2018).

Moments such as these are difficult to analyse systematically within the context of an election. Furthermore, in Malaysia, election campaign periods are extremely brief - candidates were only allowed to campaign for 11 days between nomination day and polling day in 2018 . During such campaigns, political candidates rehearse and deliver numerous speeches to different audiences within intense time constraints. Malaysia also practices a Westminster-style parliamentary system - general election campaigns are, in theory, contests between political parties rather than individual candidates. Yet, as part of their campaign speeches, candidates or their speech writers often try to weave in humour, wit, and intensity to galvanise large crowds in almost carnival-like surroundings. ${ }^{2}$

Within this context, press conferences are highly performative events, with politicians primed to stay on message when answering questions from journalists. Yet press conferences are riskier for politicians compared to stump speeches since they involve more conversational interactions between the candidate and the journalists present. Astute or unexpected questions could catch the politician off-guard. The ability to interact convincingly - for example, through intellect or charm - with reporters can help or hinder an individual candidate's ability to persuade the mass media to frame their campaign favourably. This article demonstrates that Mahathir was particularly adept at negotiating press conferences through his use of humour. However, this article cannot conclude whether Mahathir's quips were funny to everyone present or how they were received amongst different sectors of the general public within and outside Malaysia. Yet what is clear from the example given above is that the soundbite from Mahathir's victorious press conference - "Yes, yes, I am still alive" - appealed to journalists as a way of framing the significance of the PH's electoral victory.

This article further demonstrates that this was not an isolated instance of Mahathir's spontaneous humour having an effect on the media coverage of his campaign and leadership. I argue that these instances helped to construct a political identity for $\mathrm{PH}$ as a new coalition and

\footnotetext{
${ }^{1}$ Malay names are patronymic, so it is correct to cite first names upon second mention.

${ }^{2}$ Based on observations from my experiences as a Malaysian voter and a journalist who covered several byelections.
} 
for Mahathir to reconstruct his own political identity. I also critically examine how sustainable these interconnected identities were after the PH's electoral success. In doing this, I acknowledge that the social impacts of political humour should not be overstated (Tsakona \& Popa 2011: 1-2). In most instances, political humour does not, or cannot, lead to or induce lasting social change. The aim of this article is therefore not to take a strong position on whether political humour produces social change, but to analyse how it fits into the broader context of transitional political environments.

I begin by explaining how this article fits into two relevant conceptual frameworks - the role of spontaneous or conversational humour in social interactions and a sociological perspective on the concept of identity. The article then provides some relevant background on Mahathir's political career in the leadup to the 2018 general elections and elaborates how and why I have chosen to analyse the humorous moments in his press conferences. I then analyse these selected instances within a three-fold theory of identity construction. The conclusion clarifies that while spontaneous humour provided an effective means to carve out a viable political identity for the $\mathrm{PH}$, this effect was ephemeral and unstable. However, in concluding this I also acknowledge my study's limitations, in that I focus on the humour generated by Mahathir and his PH allies as reported or recorded in online media. Further questions should be explored regarding its wider reception and impacts.

\section{Conversational humour and identity construction}

Sociologists agree that laughter and humour have social meanings and functions (Zijderfeld 1983a: 6, 1983b: 30). Socio-linguists further argue that one of the most common social functions of humour is the construction of solidarity and in-group identity (Archakis \& Tsakona 2005: 42). This is true of textual, visual or more structured presentations of humour, such as cartoons or comedy routines, as well as the role of humour in the "social interaction of everyday talk" (Archakis \& Tsakona 2005: 43). In such scenarios, the kinds of humour that we use or respond to appreciatively "are major factors in the relationships we maintain and the identities we construct in and through them" (Norrick 2009: 261). Among the key dimensions of such conversational humour, a few are particularly relevant to this article - conversational or spontaneous humour as a form of performance; the relational aspects of such performances and their power dynamics; and the ways in which these performances, relationships and power structures contribute to the construction and maintenance of individual and group identities.

Regarding the performance element, according to Norrick (2009: 268), a crucial ingredient of successful joke-telling is a sense of timing. Whilst Norrick (2009: 263) makes this observation specifically in relation to jokes and joking, his insights are relevant because the humorous moments in Mahathir's press conferences illustrate the "joking relationships" he had with the mass media. The performance dimension of these press conferences also involved spontaneous wordplay in Mahathir's responses that were also characteristic of everyday talk (Norrick 2003: 1334).

The recurrence of these humorous instances illuminates their relational effects - by invoking the laughter of the journalists present, Mahathir was inviting a form of audience participation in his press conferences (Norrick 2003: 1339). At times, he had a more confrontational style but, at others, he could be quite playful - both sides of self-presentation contributed to politician-media or speaker-audience rapport. Yet, in terms of power dynamics, this rapport was also a form of control. In other words, during the tensely fought election campaign, Mahathir employed improvised humour, sarcasm and wit to avoid being "the speaker who lost the floor" (Norrick 2003: 1340). The power relations in these spontaneous performances allowed Mahathir to "present an identity for ratification" by his audience (Norrick 
2009: 267). In return, his audience - the mass media - punctuated and enhanced their narrative of the election with the social data they gathered from these media events. In this way, Mahathir, the PH and the mass media contributed to the construction of the PH's political identity - as a viable coalition with a fighting chance - during the campaign.

These dimensions of the conversational or spontaneous humour in Mahathir's press conferences need to be understood within the context of Malaysia's authoritarian political environment. Prior to the 2018 election, successive BN regimes regularly cracked down on creative dissent. In the runup to the elections, the artist Fahmi Reza was jailed for depicting the then Prime Minister Najib Razak as a clown, whilst the political cartoonist Zunar was also frequently threatened and harassed by the authorities (Ananthalakshmi 2016; NST Online 2018). Yet, even the most authoritarian regimes have a range of "allowable humour" (Oring 2004: 216). In the case of Malaysia, different phases and degrees of political censorship have influenced the culturally specific elements of Malay-language humour within a multi-ethnic and multireligious society.

Of particular relevance to Mahathir's political career is the theme of the dilemma in Malay humour (Provencher 1990: 27). This element gained prominence after the publication of Mahathir's controversial, polemical tract, The Malay Dilemma. Written while he was in political exile (summarised in Section 4), the book argued that the country's inequalities were mainly to do with race - namely, that the Malays were docile and complacent, and so were outperformed by the Chinese, who were hardworking and aggressive (Kamm 1981). The argument was incendiary and the book was banned upon publication in 1970 until Mahathir became prime minister in 1981, thereafter spawning numerous jokes, puns and innuendos in Malaysian political humour. This significant moment in Mahathir's political career went on to define his 22 years of leadership and its aftermath.

This cultural dimension of political humour in Malaysia provides necessary context for the 2018 elections. However, there needs to be further clarity on how humour specifically relates to identity construction because the very concept of identity is heavily contested.

\subsection{The dimensions of identity construction}

The concept of identity can be used in multiple and contradictory ways. According to the sociologist Rogers Brubaker and the historian Frederick Cooper (2006: 35), it is a concept that is "made to do a great deal of work," often leading to vague analysis. They argue that in academic and non-academic circles, it has been used

to highlight noninstrumental modes of action; to focus on self-understanding rather than selfinterest; to designate sameness across persons or sameness over time; to capture allegedly core foundational aspects of selfhood; to deny that such core, foundational aspects exist; to highlight the processual, interactive development of solidarity and collective self-understanding; and to stress the fragmented quality of the contemporary experience of self, a self unstably patched together through shards of discourse that are contingently active in differing contexts.

Because of the confusion arising from these conflicting interpretations, Brubaker \& Cooper (2006: 35) recommend abandoning the term identity, substituting it instead with "three clusters of terms" to refer to particular individual and social phenomena. Whilst this article does not entirely drop the word identity, it draws upon these analytical clusters proposed by Brubaker \& Cooper. In other words, when it is suggested that humour functions as a form of identity construction, the levels or aspects of identity being referred to need to be clarified.

First, there is the question of identification and categorisation, or how people are identified and categorised by others as well as how they identify and categorise themselves (Brubaker \& Cooper 2006: 41). In this line of analysis, the state can be regarded as a "powerful "identifier" 
since it has the "material and symbolic resources" to impose categories that structure how those within its jurisdiction define themselves (Brubaker \& Cooper 2006: 43). This line of analysis is useful for examining how humour addresses or influences peoples' identification or categorisation of themselves and others.

Second, there is the more fluid notion of our "self-understanding and social location," which can shift depending on the situations we find ourselves in (Brubaker \& Cooper 2006: 44). In many settings, "people may understand and experience themselves in terms of a grid of intersecting categories; in others, in terms of a web of connections of differential proximity and intensity." From this line of analysis, we can investigate how humour expresses or captures people's fluctuating or changing sense of self in specific scenarios, or how it coheres and consolidates a transformed sense of self.

Third, there is the element of "the emotionally laden sense of belonging to a distinctive, bounded group, involving both a felt solidarity or oneness with fellow group members and a felt difference from or even antipathy to specified outsiders" (Brubaker \& Cooper 2006: 46-47). This line of analysis is referred to explicitly in many discussions about humour and identity, i.e. in how humour can contribute to the formation of in-groups and out-groups, and how it creates a "feeling of belonging together" amongst insiders.

This article draws upon this tri-dimensional model by Brubaker \& Cooper (2006) to investigate the implications of the spontaneous or conversational moments of humour in the 2018 elections. Before discussing the relevant examples, however, the parameters and rationale for choosing these examples will be explained.

\section{Identifying spontaneous humour in the 2018 elections}

Academic studies have acknowledged the role of humour in election campaigns in democratic and authoritarian contexts, especially online. This includes the role of internet memes in the 2015 Nigerian elections (Adegoju \& Oyebode 2015), broader forms of online humour in the 2005 UK elections (Shifman et al. 2007), and humorous election folklore in Belarus (Astapova 2017). Studies such as these examine genres and instances of humour produced by members of the public, internet and social media users, mass media practitioners, and the election machinery of different political parties. This article contributes to this area of research by looking at spontaneous or conversational humour generated by a prominent political leader during an election campaign within a transitional authoritarian regime.

To be clear, Mahathir's humour was not an anomaly in the 2018 elections. For example, when the Election Commission banned images of Mahathir and Anwar from appearing in the PH's campaign materials, PH candidates merely continued printing posters with images of Mahathir and Anwar adorning them, but with perforated outlines accompanied by the instruction Sila potong di sini ("Please cut here"; Zamlus 2018). Another example is from the first postelection sitting of Parliament on 16 July, when the King, just before delivering his Royal Address, quipped in Malay: "Honoured members, please sit down and don't run" (Harian Metro [Daily Metro] 2018). In the tensely fought election and its aftermath, the King playfully telling parliamentarians "don't run" somewhat helped to calm anxieties about the unprecedented change of His Majesty's Government and Opposition. All sides of the political divide roared with laughter, and even the King could not help chuckling at his own joke. The references to Mahathir's spontaneous humour in this article are therefore part of a wider ecosystem of election-related humour.

Furthermore, the idea that a formidable leader such as Mahathir could be the producer of spontaneous or conversational humour is also not unique. Journalists and observers have also commented, for example, on the spontaneous humour and wit of former US President Barack 
Obama (Smith 2010). My aim, however, is to study the function and role of humour not just in relation to Mahathir's public or private persona, but as part of the interactional dynamics of identity construction in the historic 2018 Malaysian elections.

Such spontaneous moments are nevertheless difficult to identify comprehensively and systematically. Another challenge is defining exactly which moments could be categorised as humorous. According to Archakis \& Tsakona (2005: 44), the presence of laughter is often used to "characterise an utterance or a text as humorous." Yet, while laughter should not be overlooked, we must remember that humour "does not always result in laughter and laughter is not always an outcome" of humour. Bearing this caveat in mind, this article looks for instances when Mahathir appears to have intended to elicit laughter as a "desired effect" (Archakis \& Tsakona 2005: 45) through his speech and actions. I use purposive sampling to examine either YouTube videos in which Mahathir's utterances or actions were greeted by audience laughter, or media reports from independent media outlets (i.e. the outlets not controlled by Malaysian political parties) that described Mahathir's quips as funny or other adjectives that imply the presence of humour; or those which reported audience laughter at Mahathir's quotes. In selecting these examples, I am also guided by my previous ethnographic fieldwork - and prior to that my accumulated experiences as a journalist and human rights worker - in researching the intersections of religion, ethnicity, gender and politics in Malaysia.

For clarity about the sequence of dates in the 2018 elections - Parliament was dissolved on 7 April, candidate nominations were announced on 28 April, and polling was on 9 May. However, I do not restrict myself to the official 11-day campaigning period, which was the legally allowable minimum (Hutchinson 2018: 595). This is because the election was initially forecasted to be held in late 2017, meaning that the $\mathrm{BN}$ and the $\mathrm{PH}$ were on high alert months beforehand and were already in unofficial campaigning mode (Hutchinson 2018: 594). My purposive sample therefore includes one example from 2017, as well as other post-election moments in 2018, i.e. during the PH government's post-victory honeymoon period. As a postscript, I include some brief observations about the collapse of the PH government in March 2020 and the country's subsequent political instability in the midst of the coronavirus pandemic. As explained in Section 2.1, I analyse these instances by drawing upon a sociological conceptualisation of identity, i.e. according to the tri-dimensional model proposed by Brubaker \& Cooper (2006). It is beyond the scope of this article to apply discourse analysis.

To make sense of the specific humorous dimension of these moments, I will now provide a summary of Mahathir's long political career before the historic 2018 elections.

\section{Mahathir's political legacy and comeback}

Before Parliament was formally dissolved, a public forum on the question of political leadership was organised by the Malay-language tabloid Sinar Harian ("The Daily Ray"). Unlike most Malay-language print newspapers, Sinar Harian is not owned by the United Malays National Organisation (UMNO), the senior partner in the BN coalition. The forum, entitled "Is Mahathir too old to become Prime Minister?", consisted of panellists who were pro- and anti-Mahathir but pointedly did not include Mahathir himself.

About an hour after the panel began, Mahathir, his wife Siti Hasmah Ali, and their small entourage gate-crashed the forum, with Mahathir taking a seat in the front row facing one of his most vocal critics on the panel. He then tweeted a picture of himself, accompanied by a message in a mixture of Malay and English (with the original Malay in italics for clarity): "There's a forum titled 'Is Mahathir too old to become PM?' I'm attending. I'm here guys. Say it to my face" (Mahathir 2018). 
Mahathir's message was retweeted more than 13,000 times and received more than 12,000 "likes," despite the BN's censorship of favourable media coverage of opposition parties. In an added twist, the organisers asked Mahathir to take a photograph with all the panellists after the event's conclusion, making him stand beside his most vocal critic. The facial expression of this panellist - the political scientist Kamarul Zaman Yusoff - also went viral and became the butt of many jokes on social media (Malaysiakini 2018). Although this episode does not qualify as a spontaneous or conversational example of Mahathir's humour, it does provide useful background and insight into the context of his participation in the 2018 elections. This section sketches the background of Mahathir's legacy in post-independence Malaysia (Hutchinson 2018: 583-588).

During the 1960s, Mahathir was a maverick within UMNO. He famously fell out with the country's first Prime Minister, Tunku Abdul Rahman, and was expelled from UMNO, re-joining only after the second Prime Minister, Abdul Razak Hussein, assumed office. Mahathir swiftly rose within the ranks and became the country's fourth prime minister in 1981, before retiring in a tearful, much-publicised speech in 2003. Mahathir's administration is largely credited for transforming Malaysia from a largely agricultural economy to an industrial and technological powerhouse. It also had its sinister elements - Mahathir silenced his critics mercilessly, most infamously in the political and judicial crisis of the late 1980s, culminating in the detention without trial and torture of more than 100 political dissidents, journalists and social justice activists under the Internal Security Act. At this time, he narrowly retained power, aided by allies such as Anwar Ibrahim, an Islamist student activist back in the 1970s who joined UMNO when Mahathir assumed power. Mahathir reacted by undermining the institutions of the monarchy, Parliament and the judiciary to consolidate power, but faced another political and economic crisis in the late 1990s, which saw public protests toppling authoritarian regimes in the Republic of Korea and neighbouring Indonesia. This time, Anwar, by now Deputy Prime Minister, opposed Mahathir's leadership, and was sacked on charges of corruption and sodomy and imprisoned in a highly controversial trial.

After his resignation, Mahathir remained in the political spotlight, publicly condemning the administration of Abdullah Ahmad Badawi, his successor, under whose administration Anwar was released from prison. After the BN's poor showing in the 2008 elections, Mahathir orchestrated protests within UMNO to call for Abdullah's ouster, paving the way for Najib Abdul Razak (son of the second prime minister) to become the sixth prime minister. The 2013 elections saw Najib narrowly retain government, amid growing outcry over corruption and the resurgence of the opposition coalition, led by Anwar. Anwar was then charged and jailed on a separate set of sodomy charges and, despite increasing public disenchantment, Najib was widely predicted to retain power in the 2018 elections (Hutchinson 2018: 582-583).

Unexpectedly, however, anti-Najib forces within UMNO became more strident and eventually broke away to found a new political party, the Malaysian United Indigenous Party (Bersatu), led by Mahathir and his allies (Hutchinson 2018: 588-594). At the same time, the more middle-class and urbanised dissenters within the opposition Malaysian Islamic Party (PAS) also broke ranks to form the National Trust Party (Amanah). This further fragmentation of Malay-based parties in Malaysian politics forced a realignment of strategic coalition-building, in which Mahathir played an integral role. UMNO remained in charge of the BN, but PAS removed itself from the multicultural coalition of opposition parties that it had joined which included the secular-leftist and Chinese-majority Democratic Action Party (DAP) and the centrist, multi-ethnic, and (de facto) Anwar-led People's Justice Party (PKR).

A major turning point occurred when Mahathir publicly mended fences with Anwar at one of the latter's court appeals, and soon afterwards a new opposition coalition (the $\mathrm{PH}$ ) was born, consisting of PKR, DAP, Bersatu and Amanah. This development was met with further repression by the Najib administration. Analysts predicted that the splintering of UMNO and 
PAS would only benefit Najib. Yet despite the BN's most strenuous efforts at manipulating the status quo, including by disenfranchising registered voters, 82 per cent of the Malaysian electorate participated in the polls on 9 May. In the wake of the upset, Najib was forced to resign and, once again, Mahathir assumed office as Malaysia's prime minister. Power struggles within Bersatu and PKR, however, led to a series of defections from both parties and the eventual collapse of the PH government in March 2020.

Mahathir's long political career and his legacy can be analysed from different angles. For the purposes of this article, Mahathir's legacy should be understood within the context of what commentators and analysts have said about his public persona and charismatic authority, or the "Mahathir effect." By doing this, the role of humour in his presentation of self and within the larger political dynamics in Malaysia can be clarified.

\subsection{The "Mahathir effect?"}

The first Mahathir era (1981-2003) was also the era of strongman authoritarianism in the rest of Southeast Asia, notably in the Philippines under President Ferdinand Marcos (1965-1986), Indonesia under President Suharto (1968-1998), and Singapore under Prime Minister Lee Kuan Yew (1959-1990). Marcos and Suharto were overthrown by popular protests, while Lee stepped down as premier in 1990 but was given the official roles of Senior Minister (1990-2004) and Minister Mentor (2004-2011) in Singapore's subsequent administrations. Of this cohort of authoritarian leaders, Mahathir remains the only one to have resigned voluntarily neither as a result of regime change nor instigating one, and without continuing to occupy an official role in the government. This does not mean Mahathir remained silent in retirement. His public criticisms of his successor Abdullah and Abdullah's successor Najib are well-known and have already been referred to above.

Mahathir's confrontational style is one of the most recognisable aspects of his public persona. He has been described in the following ways by his political analysts and biographers - as an "elusive," "unapologetic" political "maverick" and "outsider" who is full of "contradictions" but always "speaks for himself" and is constantly "bucking the system" (Wain 2009: vi-vii); as an "abrasive personality" who imposed "non-conformist policies," an antiSemite and an outspoken critic of the West, and a statesman who was always "charming," "personable," and "courteous to foreign visitors" (Stewart 2003: 1-10); and as a "confrontational" leader famed for his "assertiveness" and "strong political will" (Milne \& Mauzy 1999: 2, 4). Mahathir's outspokenness about Western hegemony also meant that he was much more demonised in Western circles compared to his equally authoritarian peers such as Singapore's President Lee, whom the US admired because he staunchly supported its military presence in the region (Stewart 2003: 7). At the same time, this stance made Mahathir very popular amongst many Muslims within and outside Malaysia, even whilst a significant proportion of Malaysians remained critical of his domestic actions.

These recurring motifs about the force of Mahathir's persona provide the context for recent analysis about the "Mahathir factor" or "Mahathir effect" in the outcome of the 2018 elections (Abdullah 2019: 527-528). Other recent and past analysts have urged caution about overemphasising the Mahathir factor. On one hand, the damaging impacts of the BN regime's colossal 1MDB corruption scandal and the BN's subsequent implosion cannot be ignored (Welsh 2018: 87). Also, taking a longer view, democratic institutions are weak in Malaysia and this has historically enabled strong personalities to dominate the political sphere (Mauzy \& Milne 1999: 4). Yet it is because of these institutional factors that an analysis of the influence of spontaneous humour on the 2018 elections is so vital. What can these instances of humour illuminate about the dynamics of political transition within an authoritarian regime? This question is also important because mentions of the "Mahathir effect" or the "Mahathir factor" 
rarely account for humour as a component of Mahathir's public persona. The next section examines key episodes of Mahathir's spontaneous humour according to the three clusters of identity analysis by Brubaker \& Cooper (2006).

\section{Spontaneous humour and the construction of political identity}

Mahathir's sense of humour has occasionally been highlighted by journalists, including in the summaries of his legacy after the end of his first era in power. After announcing his retirement in 2003, he said he would be even "more irresponsible after I have stepped down." He explained: "[b]ut probably not being the prime minister, people won't take notice of what I say, so I'll be more free to say nasty things" (Bartlett 2003).

Mahathir lived up to this promise. For example, he remained unapologetic about his antiSemitic remarks during the financial and political crises of the late 1990s and his draconian treatment of his protégé-turned-nemesis Anwar. When Anwar was released from prison under Mahathir's successor Abdullah, Mahathir was asked whether he thought Anwar would make a good future prime minister. Mahathir replied: "He would make a good prime minister - of Israel" (Financial Times 2010).

These examples illustrate two key characteristics of Mahathir's trademark humour. First, it is "on the nose" or it states the obvious, as in the first example, where he admits that he is someone who says "nasty things." Second, it employs misdirection, as in the second example when he praises Anwar as a "good prime minister" but undermines this by associating Anwar with Israel. When he was in power, Mahathir effectively weaponised this style of humour to silence his critics. ${ }^{3}$ As the leader of an embattled political coalition in 2018, however, Mahathir's sense of humour acquired a new function, which this section now explores. I focus on two recurring themes in Mahathir's conversational humour during his press conferences and other media appearances - regarding his dictatorial past and his advanced age. Whilst some quotes could be interpreted as addressing both issues simultaneously, I separate them to analyse the identity constructions being undertaken.

\subsection{Can a leopard change its spots?}

This article began with Mahathir's off-the-cuff remark about his age during the PH's first press conference after its shock win - "Yes, yes, I am still alive." After saying this, Mahathir elicited more laughs when, just after inviting for questions from journalists, he added: "Please remember, I am a dictator" (Lee \& Latiff 2018). Both remarks - about his age and political reputation - were on the nose and provoked laughter not only from PH leaders and their many supporters, but from journalists, too. Mahathir repeated this self-referential irony regarding the "dictator" label in the immediate aftermath of his election victory. Three weeks after coming into power and appointing his Cabinet, Mahathir was asked by a journalist about the $\mathrm{PH}$ government's stand on international trade (KiniTV 2018c). Mahathir responded in English: "We haven't thought about that. But you know my personal stand on that. But now of course my personal stand is affected by my colleagues in the Cabinet." At this point, Deputy Prime Minister Wan Azizah Wan Ismail (Anwar's wife and the first woman to occupy this post in the country's history) smiled and stifled a laugh. Mahathir continued: "That is because I am no longer the dictator," eliciting audience laughter.

In other situations, Mahathir did not explicitly use the term dictator but hinted at this aspect of his legacy. In November 2018, for example, he was conferred the Distinguished Honorary 2007).

${ }^{3}$ Examples can be found in collections such as Malaysian Politicians Say the Darndest Things (Muhammad 
Patron Award by the ASEAN (Association of Southeast Asian Nations) Federation of Engineering Organisations (Zurairi 2018). In his acceptance speech, which reportedly received applause and laughter, Mahathir said: "I could have engineered a coup in my country. I tried, but I failed. So I had to resort to standing in the election." This remark combines being on the nose - in other words, would Mahathir really have staged a coup if it stood a better chance of success than standing in democratic elections? - with misdirection, by putting the concepts of "engineering" and "coup" together. While this quote does not strictly conform to the requirement of spontaneity, since it was part of a prepared acceptance speech, it illustrates how Mahathir continued to craft his public persona as a leader of the PH after taking power.

In another example, during the October 2018 Port Dickson by-election in which he supported the candidacy of his ex-nemesis Anwar (who subsequently won and was returned to Parliament by a landslide), Mahathir again played on this theme (KiniTV 2018d). Touching upon the country's finances, Mahathir said in Malay: "We will leave financial matters to [Finance Minister] Lim Guan Eng because he managed to turn the Penang state government's deficit into a surplus. I hope we [i.e. the federal government] will be able to achieve a surplus, too." At this point, Mahathir turned to face Lim, who was off-camera, triggering the audience's laughter. Mahathir turned back to the audience and continued, pointing at Lim, who was still off-camera: "If he's not successful, I'll shoot him." The audience cheered and roared with laughter, and Mahathir quipped playfully: "So violent [of me]." He quickly shifted tone and began to provide details on the PH government's reformist policies.

In these situations, Mahathir used humour to comment directly upon the incongruity of his rapprochement with his severest critics. Apart from sacking Anwar in 1998 and jailing him the following year, Mahathir also jailed numerous other critics without trial in the 1980s, including the DAP's Lim Guan Eng and his father, Lim Kit Siang. Mahathir's overtures to mend fences with Anwar, the Lims, and other former foes was met with incredulity in the Malaysian and international mass media. The unlikely alliance between Mahathir and his former critics also fuelled much scepticism about the PH's 2018 campaign and continued to be an issue after it came to power.

These examples illuminate how Mahathir's self-referential humour functioned along the three clusters of identity construction suggested by Brubaker \& Cooper (2006: 41-47). First, on the question of categorisation and identification, Mahathir was clearly and unambiguously regarded as a dictator and an autocrat not only by his foes but by many Malaysian voters. This prominent aspect of Mahathir's legacy was exploited by the BN in its efforts to dismiss the $\mathrm{PH}$ leading up to the 2018 elections. In accepting and playing with this label humorously, Mahathir was not only demonstrating self-awareness - he was also justifying his current democratic credentials in pragmatic terms. The kind of rapport he achieved - not just with the mass media and general audience, but with his former opponents-turned-allies - somewhat removed the sting of the dictator label.

This reinvention of his dictator persona also encapsulates the second analytical cluster identified - whether identity can fluctuate or change. Mahathir's spontaneous humour astutely sidestepped this dimension. For example, when he joked about being constrained by his new Cabinet, he was not claiming that he had an internal change of heart. Rather, he was stating that he was willing to work together with a Cabinet composed of people who might disagree with him. Again, the substance of such remarks was pragmatic. Yet the audience participation and light-heartedness evoked by such responses - for example, in his deputy Wan Azizah's suppressed giggle - illustrated that his new allies were also in on the joke.

This leads to the third aspect of identity construction - the "feeling of belonging together" or group feeling. The question here is whether Mahathir's asides were more effective at convincing the public about the PH's viability as a coalition than formal statements about their democratic pedigree might have done. This question is further complicated by Mahathir's past, 
as the staunch, Malay nationalist leader of UMNO in his first era in power. Mahathir was particularly hostile towards the centre-left, secularist, and Chinese-led DAP. Even the new party he established after splintering from UMNO, Bersatu, was founded on a Malay nationalist platform. How did Mahathir's efforts to rebrand himself as a repentant dictator relate to his past as an ethnic nationalist who used his time in power to defend and consolidate Malay group feeling? A final example, which I recount at length, illustrates the intricacies of how Mahathir's spontaneous humour addressed this group-feeling aspect of the PH's campaign (KiniTV 2018a).

In March 2018, before Parliament was dissolved, the BN-controlled Election Commission refused to grant the $\mathrm{PH}$ official recognition to contest as a coalition. Mahathir was asked at a packed press conference about the PH's response and its electoral chances in the light of this development. Mahathir's unscripted reply was initially serious. He said in English: "Whether approved or not approved, we are Pakatan Harapan. We behave like Pakatan Harapan. We work together, we discuss with each other, and this meeting of the presidential council will be the main organisation to direct all the activities of Pakatan Harapan." When he said this, Mahathir was flanked, to his right, by PKR's Wan Azizah, and to his left by Mohamad Sabu, one of the founders of Amanah, the splinter party of the Islamist PAS. The DAP's Lim Guan Eng was also present but off-camera.

Another journalist followed up with a question about Bersatu, which was also being denied legal registration by the BN-controlled Registrar of Societies. Mahathir's answers started becoming more playful, eliciting subtle giggles from the PH supporters and some journalists. He said, in English:

We notice that Najib is totally frightened of Bersatu, since we were formed. We're a young party, very few members and all that, poorly led by people with no experience, only 92 years old, but Najib wants to paralyse this party. So, they are trying to find fault with us. We have been registered, but now they are questioning this and that. And then, even if we answer, they will not approve [of our registration] because they are so afraid that Najib, when he goes to bed and gets up, he gets shivers. I notice this.

Another question about Mahathir's Plan B for Bersatu followed. This time, it was Mahathir who laughed, saying: "Plan B is Plan B. We don't tell people about Plan B." Asked whether he might instead contest under Anwar's PKR, Mahathir said: "All those things will be considered," and remained non-committal. Pressed further to say which party he would consider contesting under if Bersatu failed to obtain registration, Mahathir said: "I'm open, I'm open. I can stand for DAP, even. Maybe President of DAP." This comment elicited laughter, the loudest seemingly coming from Lim, off-camera. Mahathir turned to Lim and asked in Malay: "Would that be OK?" Upon hearing more laughter, Mahathir turned back to the journalist, who could also be heard laughing, and said in English: "He said yes." Lim, still off-camera, whispered audibly to Mahathir, who turned to look at him: "We stick to Pakatan." The entire crowd broke out laughing, including Mahathir.

This press conference was simultaneously a conversation and a mini-performance which included spontaneous responses not only from Mahathir, but also from the journalists pressing him for an answer and from Lim. Mahathir's gumption in saying that he would even consider standing as a DAP candidate was funny because everyone in the room was aware of his history with the party. Yet, the rapport displayed in this spontaneous moment went some way in constructing the PH's "feeling of belonging together" as a pragmatic, viable political coalition fighting Herculean odds. 


\subsection{How old is too old?}

Trying to convince old foes that one has repented of one's authoritarian past is one thing assuring them that one is not too old to do the job is quite another. Another recurring theme in the PH's shock victory was the fact that their prime ministerial-candidate was not only a former dictator - he was also 92. I have already referred to a public forum about Mahathir's age and implied senility in Section 4. Even in that example, Mahathir's response ("say it to my face") was characteristic of the persona described by many observers, analysts and biographers confrontational and on the nose. It is thus unsurprising that many reports of Mahathir's spontaneous humour before, during and after the 2018 elections also revolved around his quips about his age.

In October 2018, Mahathir joked that Malaysia's new retirement age was 95, drawing laughter from Malaysian residents in the United Kingdom during a stopover after addressing the United Nations General Assembly in New York (Bernama 2018). "I hope to last until my retirement," he said, in reference to his agreement with his PH allies that he would transfer power to Anwar after serving as prime minister for two years.

As with his remarks about being a dictator, Mahathir did not always explicitly refer to his age, but improvised on situations where his gaffes appeared to be age-related. In July 2017, after he was announced as the PH's chairman - and therefore the designated choice for prime minister - Mahathir led a press conference to explain the coalition's structure (KiniTV 2017). Reading from a printed sheet, Mahathir listed the names of the leaders of the different $\mathrm{PH}$ component parties, ending with Mohamad Sabu (affectionately known as Mat Sabu), the President of Amanah. Mahathir slipped and described Mat Sabu, in Malay, as "President of UMNO." Several PH supporters standing nearby corrected him softly, and Mahathir's chagrined facial expression at this gaffe drew laughter from the audience and from himself. The camera then zoomed out to include a laughing Mat Sabu in the frame. Mahathir and Mat Sabu looked at each other, laughing, and Mahathir addressed the audience again, in Malay, "I've demoted him," drawing additional laughter. Mahathir regained composure and went on to read the PH's press statement in full. Such a gaffe could have proven costly, as it was ammunition for the PH's opponents to hit out at Mahathir's advanced age and mental faculties. Instead, the video clip on YouTube, which has accumulated 877,949 views at the time of writing, garnered more than 4.5 thousand "likes," and only 257 "dislikes." Of the 523 comments - mostly in English and Malay - the words "cute" and "funny" were repeatedly used favourably to describe Mahathir's reaction.

This cutesy element also recurred in other clips, including during the official campaigning period in 2018. Addressing a huge crowd in early May (KiniTV 2018b), Mahathir said in Malay: "Ladies and gentlemen, I am very happy to see so many citizens come out to show support for Pakatan Harapan's struggle." This opening statement was greeted by loud applause and cheers. Mahathir continued: "And here, we are represented by my friends and a few candidates from the Barisan...oops!" It is clear at this point that Mahathir nearly said "Barisan Nasional" - his former coalition - but managed to catch himself. The crowd laughed, and so did Mahathir - his granddaughter, standing behind him and filming the proceedings also threw her head back and laughed. Still laughing, Mahathir corrected himself and said: "Candidates from Pakatan Harapan," to thunderous applause. He continued: "That was a slip. Sometimes when I talk, I slip back into the old ways." The audience laughed and cheered again, and Mahathir laughed as well, before continuing with the rest of his speech in a more serious tone.

There is no doubt that Mahathir reacted to these gaffes with wit, charm and humour. Yet his campaign was not only defined by gaffes such as these. Section 5.1 illustrated how Mahathir employed humour to address complex questions about his dictatorial past and the PH's strategy as an opposition coalition before May 2018 and as a reformist government afterwards. Against this backdrop, his "cute" reactions as a forgetful 92-year-old appeared to add to, rather than compromise, his appeal amongst his allies and many Malaysian voters. Another example is 
when Mahathir and his PH colleagues were asked to wave for the cameras after his first press conference as the new Prime Minister (KiniTV 2018e). Mahathir grinned and waved clownishly but good-naturedly at the audience, which elicited laughter.

As with his remarks about being a dictator, Mahathir's reactions about his age - explicitly or implicitly - can be analysed according to Brubaker \& Cooper's (2006) tripartite identity model. First, in regard to identification and categorisation, Mahathir used humour to acknowledge the outlandishness of, at 92, being the PH's designated choice for prime minister. The self-deprecating aspect of his humour, in which he acknowledged the preposterousness of being a such an old prime ministerial candidate - neutralised some of the harsher criticisms about his age. Second, in regard to the fluctuating and changing aspects of identity, Mahathir embraced his new status as an elder, retired statesman, playing the role of the "cute" and entertaining grandfatherly figure. This also went some way to diffuse his reputation as a harsh dictator. Thirdly, this register of humour portrayed him as a benign, reformist patriarch who appealed not only to the general public, but more importantly to the 'feeling of belonging together' amongst his PH colleagues as well. This tactic was risky, as it could have trivialised the PH's entire campaign. Yet because these reactions were unscripted and spontaneous, they appeared to add to the PH's momentum, especially given Mahathir's wit and savvy in other campaigning situations.

\subsection{Caveat: Regime change and humour?}

On 1 March 2020, Mahathir's former ally from Bersatu, Muhyiddin Yassin, was sworn in as Malaysia's eighth prime minister. After 18 months, the Pakatan Harapan government had collapsed due to infighting and power struggles within its two component parties, PKR and Bersatu, resulting in a wave of defections. At the time of writing, analysts have argued that Mahathir is a pivotal figure in this prolonged crisis, but the situation is much more complex compared to Mahathir's treatment of Anwar in the 1990s (Heijmans 2020). It is beyond the scope of this article to analyse the role of humour in this regime change, primarily because it did not occur through formal elections. Besides, the progression of the coronavirus pandemic shortly after this has complicated the analysis of the different causes of the PH's collapse. The months after this change of government - with yet another new coalition, the Perikatan Nasional (National Alliance), in power - have seen new levels of political uncertainty. Mahathir and his allies were eventually sacked from Bersatu and have set up yet another rival political party. The situation is still in flux but, at the time of writing, humour remains alive.

While it is beyond the scope of this article to analyse these humorous instances, a few observations can be made. In analysing the spontaneous or conversational humour generated by Mahathir during the 2018 elections, I have focused on the "supply" side of political humour. Based on triangulated media accounts - recorded, reported, or both - I have argued that these instances demonstrate the function of spontaneous humour as a form of political identity construction in the PH's election campaign. I have inferred that these humorous instances were significant because of the weakness of independent democratic institutions in Malaysia, coupled with the country's history of strong personalities dominating the political sphere. However, this article does not address the "demand" side of spontaneous political humour - in other words, its reception and impacts upon voter behaviour. The fact that the $\mathrm{PH}$ government was so shortlived, however, provides some clues for further research. For example, does political humour in transitional regimes fill the gaps or absences of strong democratic institutions? Or, does it actively inhibit institution-building? If political humour does influence voter behaviour, how sustainable, or how unstable, is it as a campaigning tool? 


\section{Conclusion}

Spontaneous humour functioned as implicit messaging to help the $\mathrm{PH}$ create a coherent political identity against formidable odds during the tensely fought 2018 elections. This was enabled by the coalition's choice of Mahathir Mohamad as their campaign leader and designated prime minister. This partnering was met with incredulity on several counts, two of which are the focus of this article - Mahathir's past as a nationalist, draconian leader, and his advanced age. While there were several other humorous instances in this election generated by political candidates (including Mahathir), party machinery, and members of the public, this article has focused on Mahathir's spontaneous and conversational humour. This is because the influence of spontaneous or conversational humour is relatively underexplored in research on electoral campaigns, especially in authoritarian or transitional regimes. Furthermore, this focus also contributes to analytical viewpoints that support or challenge the idea of the "Mahathir effect" or "Mahathir factor" in Malaysian politics.

My decision to analyse Mahathir's spontaneous electoral humour as a form of identity construction has been informed by scholarship demonstrating that conversational humour contributes to identity construction and maintenance. I pursue this line of questioning by framing this article with the tri-dimensional model of identity construction proposed by Brubaker \& Cooper (2006: 41-47). I have found evidence to support this model by clarifying the role of Mahathir's spontaneous humour in cohering the PH's identity on three levels - its identification and categorisation, its internal fluctuations and unlikely new alliances, and its "feeling of belonging together" as a political coalition. Mahathir did this by taking on and playing with the "ageing dictator" label, intentionally sidestepping questions about his true intentions by giving pragmatic responses, and using spontaneous humour to generate rapport and camaraderie with his former foes.

This, however, is a "supply-side" analysis of spontaneous political humour - it is beyond the scope of this article to analyse the reception or impacts of this humour on voter behaviour during the election and afterwards. Yet, even this supply-side snapshot reveals that there is more to the "Mahathir factor" - if we want to call it that - than personality alone. This article has illuminated the role of the mass media, internet users, and Mahathir's own colleagues in contributing to the construction of his charismatic leadership as a way of bolstering the PH's collective political identity. The use of humour in this case is risky - it might have worked tentatively during the political campaign and in the immediate aftermath of the election, but it is unclear how spontaneous humour fits into a transitional political context in which independent democratic institutions - including Parliament, the courts, and other statutory bodies - remain weak. The collapse of the PH government in March 2020 and the functions of humour as a response to this provide further avenues for research.

\section{References}

Abdullah, W. J. (2019). 'The Mahathir effect in Malaysia's 2018 election: The role of credible personalities in regime transitions'. Democratisation 26 (3), pp. 521-536.

Adegoju, A. \& Oyebody, O. (2015). 'Humour as discursive practice in Nigeria's 2015 presidential election online campaign discourse'. Discourse Studies 17 (6), pp. 643-662.

Ananthalakshmi, A. (2016). 'Malaysian political cartoonist Zunar arrested under Sedition Law'. Reuters. Retrieved June 15, 2019 from https://www.reuters.com/article/us-malaysiapolitics-arrest-idUSKBN13L0JW.

Archakis, A. \& Tsakona, V. (2005). 'Analysing conversational data in GTVH terms: A new approach to the issue of identity construction via humour'. Humour 18 (1), pp. 41-68. 
Astapova, A. (2017). 'Rumour, humour, and other forms of election folklore in non-democratic societies: The case of Belarus'. Electronic Journal of Folklore 69, pp. 15-48.

Bartlett, L. (2003). 'Mahathir leaves behind a complex legacy'. DAWN.COM. Retrieved September 27, 2020 from http://www.dawn.com/news/1065197.

BBC. (2018). 'Mahathir: "Yes, yes, I am still alive"'. BBC News. Retrieved June 15 $5^{\text {th }}, 2019$ from https://www.bbc.com/news/world-asia-44064057.

Bernama. (2018). 'Mahathir jokes about retirement age, says it's now 95'. The Edge Markets. Retrieved September 27, 2020 from http://maa.theedgemarkets.com/article/mahathirjokes-about-retirement-age-says-its-now-95.

Brubaker, R. \& Cooper, F. (2006). 'Beyond "Identity"'. In Ethnicity without Groups, by Brubaker. R., London: Harvard University Press, pp. 28-63.

Financial Times. (2010). 'Malaysia's shame: The trial of Anwar Ibrahim is an embarrassment', March 25, 2010, p. 10.

Harian Metro (the Daily Metro). (2018). 'Sila duduk, jangan lari-Agong'. YouTube. Retrieved June 15, 2019 from https://www.youtube.com/watch?v=UU9StEBj7Gg.

Heijmans, P. J. (2020). 'Anwar's rise shows 'new Malaysia' more about power than policy'. The Edge Markets. Retrieved September 27, 2020 from http://www.theedgemarkets.com/article/anwars-rise-shows-new-malaysia-more-aboutpower-policy.

Hutchinson, F. E. (2018). 'Malaysia's 14th general elections: Drivers and agents of change'. Asian Affairs 49 (4), pp. 582-605.

Kamm, H. (1981). 'Malaysia ends ban on premier's book'. The New York Times. Retrieved June 15, 2019 from https://www.nytimes.com/1981/08/26/world/malaysia-ends-ban-onpremier-s-book.html.

KiniTV. (2017). 'Mahathir accidentally names Mat Sabu as UMNO president'. Malaysiakini. Retrieved September 27, 2020, from https://www.youtube.com/watch?v=IqeyHq4VYa0.

KiniTV. (2018a). 'I can even stand as a DAP candidate, jokes Mahathir'. Malaysiakini. Retrieved September 27, 2020, from https://www.youtube.com/watch?v=BZkxuQIokoA.

KiniTV. (2018b). 'Mahathir: I'm happy for the support shown to the Barisan candidates. Oops!'. Malaysiakini. $\quad$ Retrieved $\quad$ September $27, \quad 2020, \quad$ from https://www.youtube.com/watch?v=OafTeQkVNHI.

KiniTV. (2018c). 'Dr Mahathir jokes about dictatorial past'. Malaysiakini. Retrieved September 27, 2020, from https://www.youtube.com/watch?v=yFc3nYwsj-Y.

KiniTV. (2018d). 'Dr Mahathir: Surplus or I will shoot Guan Eng'. Malaysiakini. Retrieved September 27, 2020, from https://www.youtube.com/watch?v=CJ8NnByIVrI.

KiniTV (2018e). 'Mahathir "waves" for the cameras after first press conference as PM'. Malaysiakini. Retrieved September, 2020, from https://www.youtube.com/watch?v=fkF3Rda60s.

Lee, L. \& Latiff, R. (2018). 'Mahathir, 92, sworn in as Malaysia's seventh prime minister'. Reuters. Retrieved September 27, 2020, from https://uk.reuters.com/article/uk-malaysiaelection-idUKKBN1I93E6.

Mahathir, M. (2018). 'Ada forum bertajuk, “Adakah Tun M terlalu tua untuk jadi PM?” Saya hadir. I'm here guys. Say it to my face'. Tweet. @ chedetofficial (blog). Retrieved June 15, 2019 from https://twitter.com/chedetofficial/status/976745594227113985?lang=en.

Malaysiakini. (2018). 'Lecturer who received "death stare" from Dr M resigns'. Retrieved September 27, 2020, from https://www.malaysiakini.com/news/424673.

Milne, R. S. \& Mauzy, D. K. (1999). Malaysian Politics Under Mahathir. London: Routledge.

Muhammad, A. (2007). Malaysian Politicians Say the Darndest Things. Kuala Lumpur: Matahari Press. 
Norrick, N. R. (2003). 'Issues in conversational joking'. Journal of Pragmatics 35, pp. 13331359.

Norrick, N. R. (2009). 'A theory of humour in interaction'. Journal of Literary Theory 3 (2), pp. 261-284.

NST Online. (2018). 'Fahmi Reza gets jail, fined RM30,000 over clown caricature'. NST Online. Retrieved June $15^{\text {th }}, 2019$ from https://www.nst.com.my/news/crimecourts/2018/02/337249/fahmi-reza-gets-jail-fined-rm30000-over-clown-caricature.

Oring, E. (2004). 'Risky business: Political jokes under repressive regimes'. Western Folklore 63 (3), pp. 209-236.

Provencher, R. (1990). 'Covering Malay humour magazines: Satire and parody of Malaysian political dilemmas'. Crossroads: An Interdisciplinary Journal of Southeast Asian Studies 5 (2), pp. 1-25.

Shifman, L., Coleman, S. \& Ward, S. (2007). 'Only joking? Online humour in the 2005 UK general election'. Information, Community and Society 10 (4), pp. 465-487.

Smith, M. (2010). 'Obama's surprising sense of humour'. CBS News. Retrieved September $27^{\text {th }}$, 2020, from https://www.cbsnews.com/news/obamas-surprising-sense-of-humor/.

Stewart, I. (2003). The Mahathir Legacy. Crows Nest: Allen \& Unwin.

Tsakona, V. \& Popa, D. E. (2011). 'Humour in politics and the politics of humour: An introduction'. In Studies in Political Humour, edited by Tsakona, V. \& Popa, D. E., Amsterdam: John Benjamins Publishing Company, pp. 1-30.

Wain, B. (2009). Malaysian Maverick: Mahathir Mohamad in Turbulent Times. Basingstoke: Palgrave Macmillan.

Welsh, B. (2018). “'Saviour” politics and Malaysia's 2018 electoral democratic breakthrough:

Rethinking explanatory narratives and implications'. Journal of Current Southeast Asian Affairs 37 (3), pp. 85-108.

Zamlus, N. (2018). "“Sila potong di sini" ("Please cut here”)'. Selangorkini. Retrieved June 15, 2019 from https://selangorkini.my/2018/05/sila-potong-di-sini/.

Zijderveld, A. C. (1983a). 'Introduction: The sociology of humour and laughter - an outstanding debt'. Current Sociology 31 (3), pp. 1-6.

Zijderveld, A. C. (1983b). 'Laughter: The language of humour'. Current Sociology 31 (3), pp. 26-37.

Zurairi, A. R. (2018). 'Accepting engineering award, Dr M jokes he couldn't even "engineer coup"'. Malay Mail Online. Retrieved September 27, 2020, from https://www.malaymail.com/news/malaysia/2018/11/13/accepting-engineering-award-drm-jokes-he-couldnt-even-engineer-coup/1692956. 